This is a self-archived - parallel published version of this article in the publication archive of the University of Vaasa. It might differ from the original.

\title{
Managerial work, importance of information and corporate profitability: evidence from Finland
}

Author(s): Laitinen, Erkki K.

Title: Managerial work, importance of information and corporate profitability: evidence from Finland

Year: $\quad 2017$

Version: final draft

Copyright Inderscience

Please cite the original version:

Laitinen, E. K. (2017). Managerial work, importance of information and corporate profitability: evidence from Finland. International Journal of Accounting and Finance 7(4), 301334. https://doi.org/10.1504/IJAF.2017.089392 


\title{
Managerial work, importance of information and corporate profitability: Evidence from Finland
}

\begin{abstract}
The objective of this study is to analyse the influence of CEO managerial work role and broad information on the profitability of the firm. The research model is based on five hypotheses on the relationship between work role, importance of broad information, and corporate profitability. Perceived environmental uncertainty (PEU) is expected to moderate the effects of managerial work and broad information on profitability. Managerial roles are described using the classic work roles introduced by Mintzberg (1973). The model is tested using survey data got from 196 Finnish top managers (CEO) of firms from different industries and size classes. The research hypotheses are tested by the Partial Least Squares (PLS) method. Empirical evidence gives partial support to the five hypotheses.
\end{abstract}

\section{INTRODUCTION}

The link between the characteristics of CEO and corporate profitability is regarded as one of the main trends in future leadership research (Hernez-Broome \& Hughes, 2004). Successful CEOs can positively affect profitability and generate continuing welfare to all interest groups of organization, most importantly to company owners (Adams, Almeida \& Ferreira, 2005). These potential effects are however related to the power of CEO to influence decisions (Sah \& Stiglitz, 1991). If CEO has sufficient decision-making power, his or her personal characteristics can play the central role in success (Hart \& Quinn, 1993; Waldman, Ramirez, House \& Puranam, 2001; Bass, Jung, Avolio \& Berson, 2003). These personal factors (personality, values, experience, knowledge, competences, and mental models) greatly determine how CEO approaches a given work (Mintzberg, 1994; Gottschalk, 2002). Thus, managerial work varies according to the needs of job and the approach of CEO, and can affect corporate performance. This association between top managerial work and corporate performance is however only rarely analysed in prior research (Harrison, 1978; Pavett \& Lau 1982; Laitinen, 2014). The present study contributes to this research.

Managerial work includes a large number of different tasks such as negotiating, recruiting, training, innovating, and contacting that are special to individual managers. These tasks are not carried out in an ordered and systematic way. Instead, managerial tasks are characterized by great variety, brevity, fragmentation in time and space, numerous interruptions, and encounters with others (Mintzberg, 1973; 1976; Tengblad, 2002; 2006; Hall, 2010). This kind of fragmented work can be captured by systematic behavioural work patterns or managerial work roles. The most famous and widely-adopted set of managerial work roles has been introduced by Mintzberg (1973). He observed that all activities in managerial work are involved by one or more of three basic behaviours: interpersonal contact (interpersonal roles), the processing of information (informational roles), and the making of decisions (decisional roles). These basic characteristics (intrinsic conditions) of managerial work have been found also in several further studies (Kurke 
\& Aldrich, 1983; Stewart, 1988; Kotter, 1982; Noordegraaf \& Stewart, 2000; Tengblad, 2002; 2006). This study continues the line of research based on managerial work roles introduced by Mintzberg.

The specific objective of this study is to link the Mintzberg managerial work roles of CEO with the corporate profitability to analyse the impact of CEO's work. In these work roles, information plays the central role (Mintzberg, 1973; 1976). The informational roles process information and link all managerial work together. The interpersonal roles ensure that information is provided. The decisional roles make significant use of the information in decision making. Therefore, this study integrates managerial work roles, importance of information for these roles, and their influence on corporate profitability. In this study the broad variety of information is captured by information scope (Brecht \& Merle, 1996; Chenhall \& Morris, 1986; Tillema, 2005). This study contributes to the research on managerial work but it is also related to management accounting research, since management accounting systems (MASs) have traditionally regarded as the provider of information for managers. In fact, management accounting researchers have presented urgent calls to research how managers engage with accounting information in their work (Jönsson, 1998; Hall, 2010). However, accounting information is only a small part of broad variety of information that managers engage (McKinnon \& Bruns, 1992; Hopwood, 2007). Therefore, the purpose is here to consider the role of traditional (financial) accounting information only as a part of broad information as argued by Hopwood (2007).

There are a large number of studies connecting manager personality and leadership style to organizational performance (Masi \& Cooke, 2000; Waldman, Ramirez, House \& Puranam, 2001; Tosi, Misangyi, Fanelli, Waldman \& Yammarino, 2004; Idris \& Ali, 2008; Yukl, 2012). However, there is a lack of studies connecting managerial work to performance. Prior studies on managerial work are mainly based on case studies, qualitative field studies, observation studies, survey descriptive statistics, and conceptual models (Noordegraaf \& Steward, 2000; Tengblad, 2002; 2006; Hall, 2010). The results of these studies are mainly descriptive and there are only few studies associating top management work statistically with organizational performance (Harrison, 1978; Pavett \& Lau 1982; Laitinen, 2014). Nicolini (2012: 13) concludes that these kinds of studies, listing and enumerating practices by taking them at face-value constitute a weak approach to practice. He calls for a strong programme to explain organizational matters in terms of practices instead of simply registering them. In this study, the objective is to follow this line of research connecting managerial work to the importance of information and corporate profitability.

This study also contributes to the research on the effect of the use of information on organizational performance (Chenhall \& Morris, 1986; Mia 1993; Mia \& Chenhall, 1994; Mia \& Clarke, 1999; Hoque \& James, 2000; Ittner, Larcker \& Randall, 2003; Agbejule, 2005; Seaman \& Williams, 2011). The main body of prior research is concentrated on the moderating effect of perceived environmental information (PEU) and other contingency variables on the relationship between the use of broad information and performance. The present study follows this line of research and associates managerial work, information and performance together assuming that 
the effects of both managerial work and the use of information on profitability are moderated by PEU. The link between information and performance is strategically critical. Chaffey \& White (2010: 10) conclude that information makes a great contribution to organizations as a resource to improve the performance of organizations and the individuals that work within them.

In summary, the objective of the study is to analyze how Mintzberg managerial work roles, importance of broad scope information, and corporate profitability are associated with each other when PEU is used as a moderating variable. The research hypotheses assume that managerial work roles are associated with corporate profitability and importance of broad information. It is further assumed that this importance is positively related to profitability. The effects of managerial work and importance of information on profitability are assumed to be moderated by PEU. The research model based on these hypotheses is tested as a partial-leastsquares (PLS) model for a survey of Finnish top managers (CEO) consisted of 196 usable responses. The results give partial support for the research hypotheses showing that two of the four extracted managerial role emphases have a significant influence on profitability. All four role emphases are positively associated with the use of information supporting Mintzberg's (1973) original propositions. PEU is found to moderate the effects of two managerial role emphases on profitability. However, it does not significantly moderate the effect of importance of information. The findings of the study therefore emphasize the close connection between managerial work and the importance of broad information but also the association of work roles with profitability. These findings also show the important role of PEU in this interplay.

The rest of this paper is organized as follows. In the second section, the set of the five research hypotheses is developed while the third section presents the sample and statistical methods. The fourth section presents the empirical results while the fifth section discusses the main findings. Finally, the last section summarizes the study and discusses the limitations of the approach.

\section{RESEARCH HYPOTHESES}

Figure 1 presents the research model of the study. The purpose of the model is to depict the relationship between managerial work roles, importance of (broad) information, and firm profitability. It is assumed that work roles are directly associated with the importance of broad information which both have an influence on profitability. These influences on profitability are assumed to be moderated by PEU. The model is consisted of five main hypotheses (links) about the causal relationships between the model variables. First, the model assumes that managerial work roles are associated with profitability $(\mathrm{H} 1)$. Second, it is assumed that these work roles are connected with the importance of broad information ( $\mathrm{H} 2)$. Third, it is suggested that this importance is related to profitability $(\mathrm{H} 3)$. Finally, the model assumes that the effects of work roles and importance of broad information are moderated by PEU ( $\mathrm{H} 5$ and $\mathrm{H} 4)$. 
(Figure 1 here)

\subsection{Managerial work roles and profitability (H1)}

\section{Mintzberg work roles}

Evidence shows that CEO's managerial work is characterized by great variety, brevity, fragmentation in time and space, numerous interruptions, and encounters with others (Mintzberg, 1973; Kurke \& Aldrich, 1983; Tengblad, 2002; Hall, 2010). The problem in analyzing CEO work is that there is no science in managerial work (Mintzberg, 1973). This means that senior managers do not work according to procedures that have been prescribed by scientific analysis. The quantity of work is great, the pace is unrelenting, and there is great variety, fragmentation, and brevity in the work tasks. CEO must concentrate on issues that are current, specific, and ad hoc, and to do so he or she must rely on verbal forms of communication (Mintzberg, 1971). However, Mintzberg (1973) found scientific basis for managerial work analysis when he observed that all tasks in managerial work are involved by one or more of three basic behaviours although their importance can vary from manager to manager: interpersonal contact, the processing of information, and the making of decisions. These basic characteristics of managerial job have been found in several further studies (Stewart, 1988; Kotter, 1982; Kurke \& Aldrich, 1983; Noordegraaf and Stewart, 2000; Tengblad, 2002). These characteristics are flexible to organizational environment but also to individual managers.

Steward \& Fontas (1992) argue that managerial jobs, especially those of middle managers, have changed radically after Mintzberg (1973) study. They say that jobs are more complex in their relationships and in the range of functions for which the manager is responsible. However, the tasks of managers will differ at different levels of the managerial hierarchy (Lawrence \& Lorsch, 1987). For CEO, the basic characteristics of job have remained stable although some aspects such as the geography and stakeholder relations have changed radically (Tengblad, 2002). Furthermore, these basic characteristics are similar worldwide that can serve as the rationale for developing a general theory of managerial work (Lubatkin, Ndiay \& Vengroff, 1977). Thus, in this study the basic characteristics of work introduced by Mintzberg (1973) are used as the analytic description of CEO's work.

Mintzberg (1973) defines the major dimensions of managerial work as consisting of ten main roles (organized sets of behaviours), grouped into three categories according to the intrinsic conditions. This classification of roles is the best-known and widely tested construct to describe managerial work. The three categories and the ten roles in this classification are as follows: interpersonal roles (Figurehead, Leader, and Liaison), informational roles (Monitor, Disseminator, and Spokesman), and decisional roles (Entrepreneur, Disturbance Handler, Resource Allocator, and Negotiator). The interpersonal roles are primarily concerned with interpersonal relationships referring to managing through people. The informational roles are concentrated on the information aspects of managerial work and link all managerial work together through managing by information. The decisional roles are concerned with decision- 
making referring to managing through action. Table 1 shows the typical tasks for each managerial role as delineated by Mintzberg (Fox, 1992). In all, the table includes 20 managerial tasks describing the ten roles.

(Table 1 here)

\section{Connection to profitability}

There are a vast number of studies connecting manager personality and leadership style to organizational performance (Masi \& Cooke, 2000; Waldman, Ramirez, House \& Puranam, 2001; Tosi, Misangyi, Fanelli, Waldman \& Yammarino, 2004; Idris \& Ali, 2008; Yukl, 2012). Furthermore, there is a large literature in economics, finance, and organizational theory that tries to assess the impact of managers on firm performance (Adams, Almeida \& Ferreira, 2005). The early studies found that CEO effects bring little additional explanatory power for profitability (Finkelstein \& Hambrick, 1996; Pfeffer, 1997). More fresh studies have identified many characteristics of CEO that are related to firm performance (Bertrand \& Schoar, 2003; Malmendier \& Tate, 2005). For example, Adams, Almeida \& Ferreira (2005) showed that CEO's characteristics have an impact on firm profitability but depending on organizational variables. However, the potential performance effects are related to the CEO's power to influence decisions (Sah \& Stiglitz, 1991). When the CEO has sufficient decision-making power to affect performance, he or she can play a central role in success (Hart \& Quinn, 1993; Tripsas \& Gavetti, 2000; Waldman, Ramirez, House \& Puranam, 2001; Bass, Jung, Avolio, \& Berson, 2003).

Thus, prior studies have analyzed the influence of many CEO characteristics in many contextual environments on firm profitability. However, there is only little evidence on the effects of CEO work roles on performance. Harrison (1978) developed a composite financial index and compared the amount of time that successful and unsuccessful CEOs spent in each of Mintzberg's ten roles to this index. Harrison concluded that successful CEOs engaged in more leader (interpersonal role) and monitor (informational role) tasks. Successful CEOs also spent less time in resource allocator and disturbance handler tasks (decisional roles) than less successful counterparts and more time in entrepreneur (decisional role) and liaison (interpersonal role) tasks.

Pavett \& Lau (1982) showed that in their sample of 48 middle-sized manufacturing firms managerial performance (job skill, quality of work, dependability, quantity of work, human relations ability, cost effectiveness and leadership) was in a statistically significant way positively associated with the importance of the liaison (interpersonal) managerial role and negatively with the leader (interpersonal) role. The importance of informational and decisional roles was not significantly correlated with performance. However, one of the three informational roles (disseminator) and three of four decisional roles (entrepreneur, disturbance handler, and negotiator) had a negative correlation. 
Luthans, Rosenkrantz \& Hennessey (1985) conducted an observation study in three organizations for 53 managers and found that two roles or activities were significantly related to managerial success: interaction with outsiders and socializing/politicking. Floren \& Tell (2012) tried to connect managerial roles (pro-activeness, networking behavior, and managerial formality) in small firms with performance measured as growth of firms. They compared managerial behavior in six fast- and six slow-growing small firms. The results indicated that there were no significant differences in the two groups as far as managerial roles were concerned. Floren \& Tell suggested that there is a generic aspect that is common to the management in both fast- and slow-growing firms. Much of a small firm manager's work, regardless of the pace of company growth, involves this generic, non-managerial behavior (acting as a specialist or a substitute operator). Laitinen (2014) estimated the association between extracted managerial work dimension (emphasizing decisional roles) and financial performance and found a negative relation.

In summary, empirical evidence on the effect of CEO work on firm performance is mixed: some studies did not found any connection while other studies suggest negative or positive impact for different managerial work roles. Similarly, Andersson \& Tell (2009) concluded that the diverse findings in the literature are contradictory and give a paradoxical picture of the impact of the manager. In this study, it is expected that controlling for the importance of information and taking account of PEU, managerial work roles are directly associated with profitability. Therefore, the following general hypothesis is presented:

\section{H1: CEO managerial work roles are associated with firm profitability.}

Hypothesis $1(\mathrm{H} 1)$ expects a general association between CEO managerial work roles and the firm's profitability but does not propose any sign for the association. $\mathrm{H} 1$ does not hypothesize any sign because prior studies showed that it depends on the managerial roles emphasized by the CEO. Harrison (1978) found that interpersonal roles (leader and liaison) are positively associated with performance. Pavett \& Lau (1982) found a significant positive correlation for the liaison role but a negative one for the leader role. Harrison and Pavett \& Lau reported a positive association for the monitor (informational) role. However, for other informational roles (disseminator and spokesperson) Pavett \& Lau got a negative and a zero correlation. Therefore, evidence for these role categories is mixed. For the most Mintzberg decisional roles, Harrison, Pavett \& Lau and also Laitinen (2014) however found a negative association with performance. Thus, for the decisional roles, the following proposition can be presented:

\section{P1: Decisional work roles are negatively associated with firm profitability.}

\subsection{Managerial roles and information (H2)}

Information is an essential element in managerial work (Mintzberg, 1973; McKinnon \& Bruns, 1992; Tengblad, 2002). In this context, the concept of information scope is important. The scope of information specifies the dimensions along which job-relevant information is measured. In this 
study, scope of information refers to the dimensions of focus, quantification, and time horizon (Chenhall \& Morris, 1986; Tillema, 2005). The focus dimension investigates if information is internal or external. The quantification dimension examines if information is financial or nonfinancial. The time horizon dimension examines if information is future- or past-oriented (Chenhall \& Morris, 1986). Narrow (or operational) and broad (or strategic) information are the extremes of information scope (Brecht \& Merle, 1996; Tillema, 2005). On this scale, broad-scope information is external, nonfinancial, and future-oriented information, while narrow-scope information is strongly limited to internal, financial and past-oriented information (Brecht \& Merle, 1996; Chenhall \& Morris, 1986; Tillema, 2005).

Information scope is associated with the CEO's main activity of making sense of the environment and what the firm should be doing. Managers use information to identify problems and opportunities, and build mental models of the business (Mintzberg, 1976). They are usually engaged in a variety of tasks with diverse time span on complex social and organizational contexts and need likely diverse and a wide range of information for sense-making in planning and decision-making (Hall, 2010). In uncertain situations, managers tend to place greater emphasis on a sophisticated information system, which provides managers with broad information (Mia, 1993; Mia \& Chenhall, 1994). This kind of system helps CEO make sense of fragmented information and create a snapshot of business.

Senior executives use many informal and formal systems to retrieve broad information for sensemaking. Balanced Scorecard (BSC) is a good example of a formal system providing CEO with a broad scope of information (Kaplan \& Norton, 1992). Kaplan \& Norton (1996b: 76) summarize the importance for broad information as follows:

"The balanced scorecard retains traditional financial measures. But financial measures tell the story of past events, an adequate story for industrial age companies for which investments in long-term capabilities and customer relationships were not critical for success. These financial measures are inadequate, however, for guiding and evaluating the journey that information age companies must make to create future value through investment in customers, suppliers, employees, processes, technology, and innovation."

BSC is organized into four broad perspectives: financial, customer, internal business process, and learning and growth. However, recent studies indicate that even original BSC may be too narrow to capture all perspectives relevant to senior managers (Chenhall, 2005; Ittner, Larcker \& Randall, 2003). The dimensions of BSC may not be properly justified and sufficient to cover all strategically important perspectives (Norreklit, 2000).

In summary, prior studies thus indicate that CEOs in information age firms are likely to broaden their scope to include outside, non-financial and future information. Evidence shows that CEO managerial work is closely associated with information (Mintzberg, 1973; McKinnon \& Bruns, 1992; Tengblad, 2002). Tengblad (2002) has reported that CEO spends on average $23 \%$ of total working time in getting information. Together with informing and reviewing information, the information-handling tasks occupy on average $51 \%$ of the total working day. Mintzberg's three 
managerial role categories are closely associated with information, since interpersonal roles provide information, informational roles process information, and decisional roles use information. Therefore, the present research model links CEO managerial roles positively to the importance of broad-scope information and presents the hypotheses below $(\mathrm{H} 2)$. The three role categories (interpersonal, informational, and decisional) are all emphasizing information but from different viewpoints.

Hypothesis 2 (H2): CEO managerial work (interpersonal, informational, and decisional) roles are positively associated with the importance of broad information scope.

Hypothesis 2 assumes that the emphasis on each of the three managerial role categories has a positive association with the importance of broad information scope. The strength of association may differ between the viewpoints. It can be expected that the association is strongest for the emphasis on informational roles since it is directly connected with processing of information. This emphasis involves the roles of assimilating and disseminating information as and when required. Without information, these roles do not exist. Finally, it is proposed that this association is second strongest for the emphasis in decisional roles because these roles are strongly integrated with the use of broad information in decision making. In these roles, a CEO is user of information, not a provider or a processor. Mintzberg (1975) emphasized the importance of decisional roles concluding that information is not an end itself but only the basic input to decision making. These two propositions together imply that the association is weakest for the emphasis on interpersonal roles providing information. This emphasis involves activities with people working in the organization. Interpersonal roles are supportive for informational and decisional roles. Thus, the following proposition is suggested:

Proposition 2 (P2): The strength of association between CEO managerial roles and the importance of broad information is decreasing in order of informational, decisional, and interpersonal roles.

\subsection{Information and profitability (H3)}

The broad scope of information makes it possible for CEOs to obtain necessary information to make successful decisions in the long run (Hoque, 2001: 5). Senior executives are engaged in a variety of tasks on complex social and organizational contexts and focus likely on a broad perspective and a broad scope of information in order to make efficient decisions (Hall, 2010). Consequently, the purpose of broad information systems is to provide a powerful set of information to upper-level managers to help them carrying out their processes effectively (Ittner \& Larcker, 1998). Therefore, it is probable that the use of broad scope information in managerial work is positively associated with the performance of the firm as measured in terms of profitability (Daft \& Weick, 1984; Hambrick \& Mason, 1984; Sharma, Jones \& Ratnatunga, 2006). This kind of association is supported by the strong intentions of BSC. It is used by CEO to clarify, communicate, and manage strategy and many other important managerial processes (goal setting, compensation, resource allocation, budgeting and planning, and strategic feedback and 
learning) which are likely to improve managerial performance in the long run (Kaplan \& Norton, 1996: ix). It has been argued that information systems focusing on too-narrow scope do not support management processes and fail to provide top management with useful, relevant information (Johnson \& Kaplan, 1987; Fisher, 1995; Ittner \& Larcker, 1998).

While providing senior managers with broad scope of information, empirical evidence on the impact of BSC on firm performance is however mixed. While Davis \& Albright (2004) found evidence of superior performance in those firms that had adopted BSC, Neely (2008) questioned the performance impact of BSC. There is however a lot of more general evidence on the influence of the use of broad information on performance. Chenhall \& Morris (1986) and Mia \& Chenhall (1994) pointed out that broad scope information is associated with higher performance in firms facing high environmental uncertainty (PEU). Ferris \& Haskins (1988) and Mia (1989) showed that an extensive use of broad scope information leads to successful decisions because it supports managers in reducing high levels of job complexity and uncertainty. Choe (2004) reported a positive relationship between broad information and production performance. Ittner, Larcker \& Meyer (2003) reported that use of broad information has a positive relationship with stock returns. However, they could not find any significant relationship between use of information and firm profitability (return on assets or ROA) or sales growth.

Mia \& Clarke (1999) showed that the use of the broad information moderates the relationship between intensity of market competition and business unit performance. This finding indicates that organizations using broad information are able to successfully face competition in the market and improve their performance. Chong \& Chong (1997) investigated the relationships between perceived environmental uncertainty (PEU) and performance which is mediated by the degree to which the managers make use of the broad scope of information. Their study showed that the use of broad scope information positively affects firm performance. Perera, Harrison \& Poole (1997) investigated the influence of non-financial performance measurement systems on performance but did not find any significant relationship. Laitinen (2014) found only a weak positive connection between the importance of broad information and firm financial performance measured by a factor based on profitability, liquidity, and solvency. Thus, although empirical studies have reported mixed results, it is assumed that the importance of broad scope information as perceived by CEO is positively associated with firm profitability following the third research hypothesis below.

Hypothesis 3 (H3): Importance of broad information scope is positively associated with the profitability of the firm.

\subsection{Moderating effects of perceived environmental uncertainty (PEU)}

The use of broad information may not always improve performance, since improvement can be expected being conditional for PEU. In management accounting information research, uncertainty has been related to the usefulness of broad scope information (Gordon \& Narayanan, 1984; Chenhall \& Morris, 1986; Gul \& Chia, 1994; Chong \& Chong, 1997). This research has 
confirmed that PEU has been associated with a need for more open, externally focused, nonfinancial information. Gordon and Narayanan (1984: 42) found that as decision makers perceive greater environmental uncertainty, they found external, non-financial and ex ante information useful in management. Chenhall and Morris (1986) found that there is a positive relationship between PEU and a need for information that has broad scope. Mia \& Chenhall (1994) also pointed out that broad scope information is associated with higher performance in firms facing high environmental uncertainty (PEU). Thus, the effect of information scope on performance was found conditional upon PEU.

Gul and Chia (1994) suggested that when PEU is low, management is able to make relatively accurate predictions about the market. However, when PEU is high, management may require additional information to cope with the complexities of the environment. More broad information can help to reduce uncertainty and improve managerial decision-making. Their results indicated that the availability of broad scope information was associated with higher managerial performance under conditions of high PEU. Abernathy and Guthrie (1994) found that the use of broad scope MAS information had a more positive impact on performance when PEU is high than when it is low. Thus, in summary, it will be hypothesized that PEU moderates the effect of broad information scope on profitability as follows:

Hypothesis 4 (H4): Effect of broad information scope on profitability is more positive for conditions of high PEU than low PEU.

Hypothesis $4(\mathrm{H} 4)$ suggests that efficient information scope improving profitability is broader when PEU is higher. This is important since CEO's managerial work is strongly concentrated on getting, processing, and using information. Therefore, it is expected that also efficient characteristics (intrinsic conditions) of managerial job improving profitability are different for different levels of PEU. What to do under uncertainty usually requires careful debate among many people across the entire organization. Therefore, under high PEU CEO needs processes and protocols to determine how issues are raised, how deliberation is conducted, and how decisions are made (Bryan, 2010). In this uncertain situation, managers try to gain alignment spending time together (in person, by phone, or in videoconferences) to surface emerging issues, share information, debate issues, and make timely decisions. The only way to make this happen is to redesign CEO work, along with corporate processes and protocols for how the meetings are conducted (including their length, decision-making roles, and required attendees). The redesign should encompass the creation of processes that enable the rapid surfacing and formal designation of issues considered critical.

Therefore, it is expected that environmental uncertainty increases information processing within organizations because managers must identify opportunities, detect and interpret problem areas, and implement strategic or structural adaptations (Hambrick, 1982; Daft, Sormunen \& Sparks, 1988). In uncertain situations, CEO intensively scans environment to acquire superior information about the environmental opportunities and problems to increase his or her organization's performance. Daft, Sormunen \& Sparks (1988) showed that chief executives in 
high-performing organizations scanned more frequently and more broadly in response to environmental uncertainty than their counterparts in low-performing organizations. Thus, it is suggested that PEU also moderates the influence of managerial work characteristics on profitability. This kind of suggestion is also supported by leadership research (Waldman, Ramirez, House \& Puranam, 2001). Waldman, Ramirez, House \& Puranam (2001) showed that the effect of CEO leadership style on profitability is moderated by PEU because uncertainty is stressful to followers, makes organizations more receptive to charismatic effects, and allows leaders more latitude for discretion. In summary, the following hypothesis is presented:

Hypothesis 5 (H5): Effect of managerial work role on profitability is moderated by PEU.

\section{EMPIRICAL DATA AND METHODS}

\subsection{Empirical data}

The empirical data of the study are based on an internet survey carried out in 2009. The statistical sampling was based on a data bank provided by Fonecta Finder, a Finnish operator that maintains the telephone catalogue for Finnish business firms in electronic form. Moreover, this catalogue includes email addresses of the key persons in these firms. From the population in the data bank, the firms outside the scope of the study were excluded. First, as the study deals with the managerial roles it was required that the firm should have more than 10 employees which may have sufficiently organized management processes for CEO. Thus, micro firms were excluded from the sample. Second, banks and financial institutions were excluded because of the distinct nature of their operations. Third, the sample was restricted to limited companies which in Finland have a CEO according to the The Limited Liability Companies Act (LLCA). Fourth, the sample only includes firms which had email address for CEO in the Fonecta data bank.

Taking account of the four restrictions the population included 11790 firms. For the sample, each tenth of the population was randomly selected so that it included 1179 limited companies. However, due to the changes in organizations and email addresses it was not possible to reach 119 firms and the final sample consisted of 1060 limited companies. The cover letter (email) with a reference and password to the internet page of the questionnaire was sent to the email address of the CEO in the firm. To ensure the reliability of the responses and to complement the data later the possibility to recognize and check the respondent was maintained. After eight weeks and three follow-up emails, 222 firms (20.9\%) responded to the questionnaire. Because of missing values in model variables 26 questionnaires were excluded from the later analyses. Thus, the final sample included 196 firms with non-missing task data so that the response rate was $18.5 \%$ which can be regarded as satisfactory. The sample firms represent different industries and $31.6 \%$ of the firms are service firms while $25.0 \%$ and $16.3 \%$ belong to manufacturing and trade industries, respectively. In general, the firms are small businesses and about $50.8 \%$ of them employ less than 30 employees. Therefore, CEO in these firms can have extensive power for decision-making. 


\subsection{Variables}

Management work role and task variables

The CEO managerial work is measured by the perceived importance of the role tasks originally introduced by Mintzberg (1973). This classification of roles is the best-known and widely tested construct to describe managerial work. Mintzberg (1973) defines the major dimensions of managerial work as consisting of ten main roles, grouped into three categories: interpersonal roles (figurehead, leader, liaison); informational roles (monitor, disseminator, spokesperson); and decisional roles (entrepreneur, disturbance handler, resource allocator, negotiator). The ten roles are based on brief summary of the basic tasks in these roles. In the present survey, the work roles were examined more accurately using the typical tasks as delineated by Mintzberg. There are two tasks per each role making 20 tasks altogether. This survey tool has been successfully used by Fox (1992). The importance of the tasks was assessed by a question how important CEO considers each of the twenty tasks for his or her managerial work on a 7-point Likert scale from 1 (not important at all) to 7 (extremely important) (see Appendix 1 for the scales of the variables). The tasks are described in Table 1 discussed earlier.

The twenty managerial work role tasks are theoretically associated with three different intrinsic Mintzberg role categories and are supposed to form an integrated whole. Mintzberg (1976: 18) states himself that:

"It should be clear by now that the 10 roles I have been describing are not easily separable. In the terminology of the psychologist, they form a gestalt, an integrated whole. No role can be pulled out of the framework and the job be left intact".

Statistical tests supported this conclusion, since the factors extracted for each category of roles separately did not fulfil requirements for discriminant validity (for distinct variables). Therefore, the original role categories are not separated but instead the emphasis given by CEO on different roles is measured by distinct factors. The different emphases (latent variables) are extracted by the factor analysis based on the maximum likelihood estimation (SPSS) and Varimax rotation. The number of factors is determined by the-eigenvalue-greater-than-one rule (K1 or Kaiser criterion, see Kaiser, 1960). Panel 1 of Table 2 presents the eigenvalues for factors 1 to 10 . The K 1 criterion leads to the choice of the four-factor solution explaining $56.1 \%$ of the total variance of the 20 original task variables.

The rotated four-factor solution explains $47.1 \%$ of the total variance of the task variables. Panel 2 of Table 2 shows the rotated factor loadings of different factors on the tasks. Factor 1 (explaining for $17.0 \%$ of the total variance) has high loadings for different categories of roles describing a mixed emphasis. This obviously refers to the integrated nature of work roles. However, the three highest loadings are got by tasks 9 and 10 (disseminator) and task 7 (monitor) which all represent informational roles. Therefore, this latent variable is called here Emphasis on informational roles. For factor $2(14.5 \%)$, the clearly highest loadings are got by decisional tasks 13 and 14 (entrepreneur) but also informational tasks 11 and 12 (spokesman) show high loadings. 
This mixed factor is thus entitled as Emphasis on decisional-informational roles. Factor $3(9.4 \%)$ has got high loadings only on decisional tasks 19 and 20 (negotiator) and can thus called as Emphasis on decisional roles. Factor $4(6.2 \%)$ is strongly associated only with interpersonal task 2 (figurehead) and represents obviously Emphasis on interpersonal roles.

\section{(Table 2 here)}

\section{Importance of information}

Appendix 1 shows the questionnaire of the study that specifies the exact questions used and their response scales. The question about the importance of information presented to CEO in the questionnaire is: how important do you consider the following types of information in your managerial work? The use of broad information is reflected in the research model by the construct for the importance of the scope of information in managerial work. The scope of information is measured as the perceived importance of the three dimensions of scope (focus, quantification, and time horizon) in CEO work (Tillema, 2005). The focus dimension (contrasting information within and outside the firm) and the quantification dimension (contrasting financial and non-financial information) are measured by two items and the time horizon dimension (contrasting information from past and future events) by three items on a 7-point Likert scale from 1 (not important at all) to 7 (extremely important). The questions for these seven items were accompanied with examples for each item to support assessment of importance.

\section{Profitability}

When assessing the research hypotheses on the effect of managerial work and the importance of broad information on profitability, it is important that the time lag between the measurement and the survey moment is long enough, at least 1-2 years (Ling, Simsek, Lubatkin \& Veiga, 2008; Waldman, Ramirez, House \& Puranam, 2001; Waldman, Javidan \& Varella, 2004). Since the last survey responses are got in the beginning of 2009, the profitability of the sample firms is measured for the accounting periods 2010 and 2011. Thus, the time lag between the survey time and the date of closing of accounts is on average about from 2 to 3 years. Profitability is measured by three standard financial ratios gathered from the database Voitto+ maintained by Suomen Asiakastieto Oy (www.asiakastieto.fi). Firstly, it is measured by the return on investment (ROI) ratio which relates the earnings before interest and taxes (EBIT) to the average invested capital. Secondly, profitability is reflected by the return on assets (ROA) ratio based on the ratio of EBIT to average total assets. Thirdly, profitability is measured by the profit turnover ratio which relates EBIT from business operations to turnover. In all, there are six items (three profitability ratios for two years) for the construct of profitability.

\section{PEU}

The environment of organization is here reflected by perceived environmental uncertainty (PEU) which is used as a moderating variable of the effect of managerial work roles and information 
scope on profitability. It is measured here by a general question measured on a 7-step Likert scale referring to the perceived inability of CEO to make exact business forecasts for a medium term (2-3 years) horizon (from 1 = extremely low PEU to $7=$ extremely high PEU). Thus, PEU is defined in this study as a strategic-level variable pertaining to top management's perceptions of uncertainties in the external environment (for example, competitors, customers, government regulations) summarized in general terms (Tymon, Stout $\&$ Shaw, 1998).

\subsection{Statistical methods}

The research model outlined in Figure 1 is tested by the structural equation modeling (SEM) based on the partial least squares (PLS) method (Stage, Carter \& Nora, 2004). This method has been used quite frequently in management accounting and social science research (Baines \& Langfield-Smith, 2003; Luft \& Shields, 2003; Smith \& Langfield-Smith, 2004). PLS is useful especially when the sample size is limited and the theory is not strong. In addition, PLS is able to accommodate non-normal data due to less rigorous assumptions underpinning the technique (Smith \& Langfield-Smith, 2004). It can handle many independent variables, even when there are more predictors than cases and even when predictors display multicollinearity (Temme, Kreis \& Hildebrandt, 2006).

The PLS model is estimated by the SMARTPLS 2.0 (M3) software (http://www.smartpls.com/). For the latent variables reliability is measured by the Cronbach Alpha that should be equal or higher than 0.7 . Furthermore, composite reliability should not be lower than 0.6 . The reliability of indicators is measured by the absolute standardized outer loadings which should exceed 0.7 (Henseler, Ringle \& Sinkovics, 2009). Convergent validity is reflected by the average variance extracted (AVE) which should exceed 0.5. The discriminant validity is assessed by the Fornell-Larcker (1981) criterion that the AVE of the latent variable should be greater than the squared correlation of the latent variable with any other latent variables and by the criterion that the loading of each indicator on the latent variable exceeds all of its cross-loadings on other latent variables.

The structural (outer) PLS model is assessed by the coefficient of determination ( $R$ squared, $R^{2}$ ) of the endogenous latent variables. Chin (1998) describes $R^{2}$ values of $0.67,0.33$, and 0.19 as substantial, moderate, and weak, respectively. The significance of the individual path coefficients are used to assess the empirical validity of the theoretically assumed relationships using the $t$ test based on bootstrapping. Thus, the $t$-values of the parameters are calculated by bootstrapping ( 500 sub-samples). In addition, (average) communality is used to assess how much (on average) the latent variable can reproduce of the variance of its indicators. Finally, redundancy is used to reflect the percent of the variance of the indicators for a latent variable that can be explained by the independent latent variables directly connected to the latent variable. 


\section{EMPIRICAL FINDINGS}

\subsection{Descriptive statistics}

Table 3 presents descriptive statistics for the model variables. Panel 1 presents statistics for the 20 managerial task variables. In general, the figures indicate quite low standard deviation, skewness, and kurtosis for the different tasks. However, the range of values for the tasks is 1-7 (theoretical range) for all other tasks except for tasks 1, 3, 7 (1-6), and 6 (1-5). The skewness is frequently negative showing that the greater part of the mass of the distribution is located on the right side of scale reflecting the importance of the tasks. The average importance of the tasks varies between 4.850 (almost moderately much importance) to 3.200 (less than average importance). The most important tasks are 14 (4.850) and 13 (4.600) both describing the entrepreneur role of the decisional category. These tasks have got high loadings on the second factor (emphasis on decisional-informational roles).

(Table 3 here)

Panel 2 presents statistics for the construct of the importance of information scope. The highest average values are got for the focus dimension and the lowest values for the time horizon dimension. The highest average value is obtained by information on events within the firm (5.770) and outside the firm (5.680) indicating almost very much importance. The lowest average value is obtained by information related to future events mechanically based on past events (4.290) being a bit over average importance. The standard deviations of the values are not large but the range equals anyway the theoretical range 1-7 for items $2,5,6$, and 7 . For item 1 it is 2 7 and for items 3 and 4 3-7. The table also shows that the outer loadings for all seven items are positive and high exceeding 0.6. In fact, deletion of any of the items from the construct would decrease the Cronbach Alpha statistic. High positive loadings for all items of scope indicate that the construct is associated with the importance of broad scope information for CEO's managerial work.

Panel 3 shows statistics for the profitability ratios in 2010 and 2011 associated with the construct of profitability. The standard deviation of the ratios is quite high indicating a notable dispersion in the distributions. The ratios show positive skewness except for the EBIT to sales ratio in 2010 with negative skewness. For this profitability ratio, kurtosis is exceptionally high indicating deviation from normality. This non-normality does not strongly affect the results because PLS is not sensitive for deviations from normality. The deletion of the item from the construct did not affect the main results. The outer loadings for the ratios are high exceeding 0.6 . The deletion of any of the ratios would lead to a decrease in the Cronbach Alpha statistic and therefore all six ratios are kept in the construct of profitability.

\subsection{The PLS model}


Table 4 shows the statistical characteristics of the estimated PLS model. The Cronbach alpha for both latent variables exceeds the limit of 0.80 and is higher for the profitability construct $(0.89)$. The composite reliability figures also refer to a very good reliability for each construct. The AVE figures for the latent variables exceed limit of 0.50 indicating a satisfactory convergent validity of the PLS model. The figures are higher than the squared correlation between the latent role variable and other constructs showing sufficient discriminant validity. The cross-loadings between the items of the multi-item constructs are generally low and less than the loadings on the own latent variable also referring to a satisfactory discriminant validity (see Appendix 2 ). The level of redundancy for both latent constructs is very low. The $R$ squares $\left(R^{2}\right)$ show that the four managerial work factors (emphases) explain for $30.4 \%$ of the variation of the information scope. The model variables together (managerial task factors, importance of broad information scope, and PEU) explain only for $14.1 \%$ of the variation in the lagged profitability indicating a weak ability to explain (Chin, 1988).

\section{(Table 4 here)}

Table 5 presents the path coefficients for the PLS model. Two of the four managerial work role emphases (captured by latent variables or factors) are not statistically significantly associated with profitability which does not support hypothesis $\mathrm{H} 1$ for these emphases. However, emphases on decisional roles and on informational roles are both negatively in a significant way linked to profitability. These findings support hypothesis $\mathrm{H} 1$ and also proposition $\mathrm{P} 1$ about the negative relationship between decisional roles and firm profitability. The path coefficients between the four work role emphases and the importance of broad information scope are all positive and statistically significant giving strong empirical support for hypothesis $\mathrm{H} 2$. The association is clearly strongest for emphasis on informational roles supporting proposition P2. However, the differences in the strength of association are small for other managerial role emphases although emphasis on decisional roles shows the second strongest association supporting thus P2.

\section{(Table 5 here)}

The importance of broad scope information has a strong positive connection with profitability which gives clear support to hypothesis H3. The moderating effect of PEU is statistically insignificant for the impact of the importance of broad scope information on profitability conflicting with $\mathrm{H} 4$. However, it is statistically significant (2-tail significance) for the effect of two of the four work role emphases on profitability supporting $\mathrm{H} 4$. First, the effect of the interaction term of PEU and emphasis on decisional roles on profitability is strong and negative indicating that the negative effect of the emphasis is even more negative when PEU is high. Second, the effect of the interaction term of PEU and emphasis on interpersonal roles is weaker but positive indicating that interpersonal roles can be beneficial for CEO when under high uncertainty.

Panel 1 of Table 6 presents the total effects of the PLS model. The total effects of work role emphases on profitability are practically statistically insignificant (2-tailed significance). However, the negative total effect of emphasis on decisional roles is relatively strong but not statistically 
significant due to the positive indirect effect through the importance of broad scope information. In addition, the total effect of emphasis on decisional-informational roles is statistically weak but anyway positive. Panel 2 presents the bootstrap results for the test of the indirect effect of work role emphases on profitability. This kind of bootstrap test is useful when testing the significance of mediation (Zhao, Lynch \& Chen, 2010). This panel shows that all the indirect (mediation) effects are not statistically insignificant. Thus, the importance of broad information scope does not mediate the effect of managerial work on profitability in a statistically significant way.

(Table 6 here)

Figure 2 shows the main findings of the study including only statistically significant paths of the PLS model. Managerial work role variables are all strongly and positively associated with the importance of broad information scope. Emphases on decisional and informational work roles are the only managerial role latent variables which have a significant association with firm profitability. This association is quite strong and negative. The importance of broad scope information is strongly and positively associated with firm profitability. The effect of emphasis on decisional roles on profitability is also negatively moderated by PEU.

(Figure 2 here)

\section{DISCUSSION OF THE FINDINGS}

\subsection{Managerial work}

Managerial work is in this study measured by a set of managerial work tasks involved by ten roles identified originally by Mintzberg (1973) and supported later by several studies (Noordegraaf \& Stewart, 2000; Tengblad, 2002). These roles are originally classified into three broad categories (interpersonal, informational, and decisional category) according to their tasks (interpersonal contact, processing of information, and making of decisions). This study strongly supports Mintzberg's (1973) conclusion in that the three role categories form a gestalt and cannot be easily separated. Factor analysis showed that the categories are to some degree overlapping and do not form distinct dimensions. Especially some informational and decisional roles are closely associated together to form a distinct mutual factor.

Factor analysis gave four different role categories entitled according to the highest loadings on managerial tasks: informational, decisional-informational, decisional, and interpersonal category. The informational category is the dominant category with high loadings on many tasks also from other Mintzberg's categories. The decisional-informational category is a mixed combination of mainly two original work role categories. These new four categories measure the different emphases of managerial work roles given by CEOs. They summarize the basic characteristics of managerial work in four latent variables. The purpose of this study is to investigate how these latent variables (factor scores) are associated with profitability and broad scope information when perceived environmental uncertainty or PEU is taken into account. 


\subsection{Managerial work and profitability (H1)}

The findings of this study indicate that two emphases of managerial work are significantly directly associated with profitability. The emphases of informational and decisional roles have both a significant negative direct association with profitability. However, emphases of decisionalinformational and interpersonal roles are not directly linked to profitability. The weak relationship between these emphases and profitability may not be based on lack of CEO's power to influence decisions (Sah \& Stiglitz, 1991). The sample of firms in this study is consisted of limited companies where LLCA gives to CEO wide authorities to take responsibility of important decisions. The majority of sample firms are small so that the findings can partly be related to the findings of Floren \& Tell (2012). They suggested that there is a generic aspect, non-managerial behavior that is common to the management in small firms regardless of performance (growth). Therefore, all managerial roles may not be powerful in discriminating between successful and non-successful firms.

Thus, the findings give partial support to hypothesis H1. First, emphasis of informational roles is negatively connected with profitability. This emphasis is here a combination of disseminator and monitor roles. In informational roles, CEO acts as the nerve center of his or her organization. When CEO acts as a disseminator, he or she passes some of privileged information directly to his or her subordinates. In his or her monitor role, CEO perpetually scans environment for information, interrogates his or her contacts and subordinates, and receives unsolicited information (Mintzberg, 1976). This study indicates that concentration on these kinds of information roles can be negative for profitability. However, if information roles (spokesman) are combined with decisional (entrepreneurial) roles, the negative impact on profitability can vanish or the impact may even be weakly positive. This kind of combination (emphasis of decisionalinformational roles) is the only emphasis that had positive (although insignificant) connection to profitability. This finding indicates that handling of information should be closely connected with decision making to inhibit negative effects.

Second, emphasis on decisional roles is also negatively associated with profitability indicating in the same way that these roles should be connected with informational roles in order to inhibit negative effects on profitability. This negative association gives anyway support to hypothesis $\mathrm{H} 1$ and is consistent with proposition P1. It is also consistent with findings of Harrison (1978), Pavett \& Lau (1982), and Laitinen (2014). The emphasis of decisional roles is here strongly based on the negotiator role where CEO participates in negotiation activities with other organizations and outside individuals. This role is necessary for CEO because he or she is organization's authority, its spokesman and its resource allocator. CEO takes charge whenever the firm must enter into important negotiations. However, evidence indicates that the more CEO assigns importance to negotiations with external parties, the lower is the firm's profitability. This conclusion does however not mean that any interaction with outsiders would not be recommendable. Luthans, Rosenkrantz, \& Hennessey (1985) concluded that interaction with outsiders was significantly related to managerial success. 
In the hierarchical taxonomy of leadership behaviors introduced by Yukl (2012) the decisional emphasis based on the negotiator role belongs to the category of external leadership behaviors and therein in the representing sub-category. Yukl also presents a list of studies providing evidence that representing is related to effective leadership (Yukl, 2012: 75). This evidence is based on survey questionnaires, research with incident diaries and interviews, and comparative case studies. However, the vast variety of behavior and performance constructs used in these studies makes it difficult to compare the findings with those of this research.

\subsection{Managerial work and information $(\mathrm{H} 2)$}

The findings show that each of the four emphases of managerial roles is positively and significantly associated with the importance of broad scope information. These findings give strong support to hypothesis $\mathrm{H} 2$ and are consistent with prior evidence on the importance of broad information to top managers (Mintzberg, 1973; McKinnon \& Bruns, 1992; Tengblad, 2002; Hall, 2010). The strongest association between emphasis and importance of broad information was found for emphasis of informational roles supporting proposition P2. In his or her informational role, CEO processes information. This information is often verbal, as gossip, hearsay and speculation. CEO has a natural advantage in collecting this kind of soft information for his or her organization (Mintzberg, 1976). Thus, the main managerial tasks of this emphasis are associated with processing of a broad variety of information making the close and strong connection with information obvious.

The findings of the study thus indicate that broad information is important for CEO's managerial work irrespective of emphasis given to different managerial work roles. Therefore, management information systems should support availability of this kind of information to CEO independently of the managerial work roles emphasized. Formal information systems are often inefficient in providing CEO with such information. In this context, Mintzberg (1976) discussed the myth that CEO needs in managerial work aggregated and narrow information, which a formal management information system best provides. His conclusion, however, was that the myth is not true. Mintzberg (1976: 8) concluded that:

"Managers have five media at their command - documents, telephone calls, scheduled and unscheduled meetings, and observational tours."

Formal documents only form a small fraction of important information that is diverse and broad (McKinnon \& Bruns, 1992; Hopwood, 2007). Therefore, informal information systems are playing the central role in satisfying CEO's needs for broad information. They are more spontaneous than formal systems and provide also flexibility and adaptation.

\subsection{Information and profitability (H3)}

Evidence indicates that broad information is not only important to managerial work of CEO but that it is also profitable for the firm. These findings support hypothesis $\mathrm{H} 3$ on the positive association between a broad scope of CEO information and firm profitability. This result indicates 
that a firm can financially benefit from management information systems providing CEO with broad information. Therefore, it is beneficial to design management information systems for CEO to produce past and future information (time horizon) on inside and outside events (focus) expressed in both financial and non-financial terms (quantification). In order to improve profitability, CEO needs for decision making traditional past financial information about inside events but beyond that also broad future, non-financial, and external information. These findings are consistent with prior research on the connection between the use of broad information and performance (Chenhall \& Morris, 1986; Mia \& Chenhall, 1994; Ferris \& Haskins, 1988; Mia, 1989; Chong \& Chong, 1997; Mia \& Clarke, 1999; Choe, 2004).

Empirical findings also revealed that the importance of broad information does not mediate the effect of managerial work on profitability in a statistically significant way. However, the indirect although weak mediation effect can anyway partly eliminate the negative effect of an emphasis on profitability or strengthen the positive effect. The findings show that the total effect of the emphasis of decisional roles on profitability is still negative but not statistically significant when the positive mediation effect partly weakens the strong negative direct effect. Moreover, the total effect of the emphasis of decisional-informational roles is more positive than the direct effect when the positive indirect effect is taken into account. Therefore, even a weak mediation effect can restrain negative effects or strengthen positive effects of emphasis of certain managerial roles.

\subsection{Moderating effects of PEU (H4 and H5)}

In this study, PEU was incorporated in the PLS model as a moderator for two effects. First, it was expected that the effect of broad scope information on profitability is more positive for high uncertainty (H4). This kind of moderating effect of PEU is in many previous studies on the field (Gordon \& Narayanan, 1984; Chenhall \& Morris, 1986; Gul \& Chia, 1994; Chong \& Chong, 1997). However, in this study the hypothesis only got weak support if any. The effect of the interaction of importance of broad information and PEU on profitability was found positive but statistically not significant. Statistical analyses indicated that the average moderating effect in the sample was strong but its high variance made the result statistically insignificant. Therefore, it can be concluded that PEU may positively moderate the effect of broad information on profitability but the moderation shows a high variance leading to that the result cannot be statistically generalized.

Second, it was expected that the effect of managerial roles on profitability is moderated by PEU (H5). In this study, this hypothesis got only partial support although it is supported by prior studies (Hambrick, 1982; Daft, Sormunen \& Sparks, 1988; Waldman, Ramirez, House \& Puranam, 2001). For the four emphases of managerial roles, only one statistically significant and one weak moderating effect of PEU was found. For the emphasis of decisional roles, the effect on profitability was found more negative under higher uncertainty supporting H5. This emphasis refers here to the negotiator role where CEO participates in negotiations with other organizations and outside individuals. Evidence shows that this kind of managerial behavior (emphasis of 
negotiations with outside parties) makes a negative effect on profitability and that this effect is even more negative when environmental uncertainty is high.

Evidence also gives weak support to $\mathrm{H} 5$ for emphasis of interpersonal roles although the result is not statistically significant. It shows that the effect of emphasis on interpersonal roles is weakly more positive when PEU is high. This emphasis is in this study strongly based only on the figurehead role. Interpersonal roles rise from the formal authority of CEO and involve his or her basic interpersonal relationships. When CEO acts as a figurehead, as a head of organization, he or she performs some duties of ceremonial nature. These kinds of duties may be sometimes routine, involving little serious communication and unimportant decision making. However, these duties are important to the functioning of the organization and cannot be ignored (Mintzberg, 1976). This study indicates that this kind of ceremonial behavior can be more beneficial when uncertainty is high.

The emphasis of interpersonal roles is closely connected with participation in different meetings within the firm. Tengblad (2002) has shown that meetings play major role in managerial work today. In his data, the average time spent in meetings was $58 \%$ of the total working hours of CEO. The average CEO had 105 meetings in a four-week period. These figures are comparable with Mintzberg (1973) and Kurke \& Aldrich (1983). The association between interpersonal roles and PEU can be explained by the concept of interactive control as introduced by Simons (1991). When uncertainty is high, interactive use of controls is beneficial to performance. This means that information is interpreted and discussed in face-to-face meetings between top management and operating managers at all levels of organization. These kinds of interactive meetings help CEO focusing on and solving strategic uncertainties which can help organizational learning and performance.

\section{CONCLUSIONS}

The objective of this study was to analyze how Mintzberg (1973) managerial work roles, importance of broad information, PEU, and corporate profitability are associated with each other. The research hypotheses first assumed that managerial work roles are associated directly with firm profitability (hypothesis $\mathrm{H} 1$ ). It was also assumed that these work roles are positively associated with the importance of broad information (hypothesis $\mathrm{H} 2$ ) and that this importance is positively associated with firm profitability (hypothesis H3). Finally, it was assumed that PEU moderates the relations between the importance of broad information and profitability $(\mathrm{H} 4)$ and between managerial work and profitability (H5). The set of these research hypotheses was tested as a partial-least-squares (PLS) model for a survey of Finnish top managers (CEO) consisted of 196 usable responses. 
Managerial work was captured by different emphases of 20 Minzberg role tasks extracted by the orthogonal factor analysis. Four different emphases (factors) of (informational, decisionalinformational, decisional, and interpersonal) roles were found. Evidence partly supported hypothesis $\mathrm{H} 1$, since the emphases of decisional roles and informational roles were directly and negatively associated with profitability. Evidence also showed that all four emphases on managerial roles are positively associated with the importance of broad information. This finding gives support to hypothesis $\mathrm{H} 2$ and to Mintzberg's (1973) conclusion that all managerial work role categories are connected with information. Findings further show that there is a positive association between importance of broad information and firm profitability consistently with hypotheses H3. However, evidence does not support H4, since PEU did not moderate this relationship in a statistically significant way. Finally, PEU moderated the relationship between managerial work and profitability negatively for the emphasis of decisional roles and positively for the emphasis of interpersonal roles. These findings give partial support to H5.

Empirical evidence showed that the importance of broad information does not mediate the effect of managerial work on profitability in a significant way. It can however partly eliminate the negative direct effect of managerial work on profitability and strengthen the positive effect. The findings indicate that irrespective of emphasis given to managerial roles, CEOs consider broad information important to their work. The importance is broad information is directly and positively associated with profitability. Therefore, management information systems should produce broad information irrespective of CEO's managerial roles or the level of perceived environmental uncertainty. The findings also indicate that CEOs should not strongly concentrate on informational or decisional roles purely but merely on the combination of these roles. It is risky to concentrate on decisional roles especially when PEU is high. The negative effects can partly be eliminated by strong relationship with broad information.

This study has several limitations which can be eliminated in further studies. Firstly, managerial work is measured by Minzberg (1973) classic model consisting ten different roles from three categories. Although being still valid, the framework is old and could be replaced by a newer one. Secondly, the broad information scope is reflected by different items referring to different scope dimensions. More advanced constructs for information should be developed and used. Thirdly, the study is concentrated on managerial work of CEO although there are notable differences in work done between different functional managers and managers from different hierarchic levels of organization. Fourthly, the results of this study are estimated by the PLS analysis that has limitations of its own. Therefore, more advanced statistical methods should be applied. Fifthly, the findings deal with Finnish senior managers only. In the future, these kinds of surveys should be carried out in other countries as well, to generalize the results. The hope is that this study inspires future scientific research on the relationship between managerial work, use of information, and the performance of the firm.

\section{REFERENCES}


Adams, R.B., Almeida, H. \& Ferreira, D. (2005). Powerful CEOs and Their Impact on Corporate Performance, The Review of Financial Studies, 18(4), 1403-1432.

Agbejule, A. (2005). The relationship between management accounting systems and perceived environmental uncertainty on managerial performance: A research note, Accounting and Business Research, 35(4), 295-305.

Andersson, S. \& Tell, J. (2009). The relationship between the manager and growth in small firms. Journal of Small Business and Enterprise Development, 16(4): 586 - 598.

Baines, A. \& Langfield-Smith, K. (2003). Antecedents to management accounting change: a structural equation approach, Accounting, Organizations and Society, 28(7/8), 675-698.

Bass, B., Jung, D., Avolio, B. \& Berson, Y. (2003). Predicting unit performance by assessing transformational and transactional leadership. Journal of Applied Psychology, 88 (2): 207-219.

Bertrand, M. \& Schoar, A. (2003). Managing with style: The effect of managers on firm policies, Quarterly Journal of Economics, 118 (4), 1169-1208.

Brecht, H.D. \& Merle, P.M. (1996). Accounting information systems: the challenge of extending their scope to business and information strategy, Accounting Horizons, 10(4), 16-22.

Bruns, W., Jr. \& McKinnon, S.M. (1993). Information and managers: a field study, Journal of Management Accounting Research, 5(2), 84-108.

Bryan, L. (2010). Dynamic management: Better decisions in uncertain times. McKinsey Quarterly, 13(1), 32-40.

Cattell, R. B. (1966). The scree test for the number of factors. Multivariate Behavioral Research, 1(2), 629-637.

Chaffey, D. \& White, G. (2010). Business Information Management. Pearson Education: UK.

Chenhall, R. \& Morris, D. (1986). Organic decision and communication processes and management accounting systems in entrepreneurial and conservative business organizations, Omega International Journal of Management Science, 23(5), 485-497.

Chenhall, R.H. (2005). Integrative strategic performance measurement systems, strategic alignment of manufacturing, learning and strategic outcomes: an exploratory study, Accounting, Organizations and Society, 30(5), 395-422.

Chin, W. W. (1998). The partial least squares approach for structural equation modeling. In G. A. Marcoulides (Ed.), Modern methods for business research (pp. 295-236). London: Lawrence Erlbaum Associates.

Choe, J. (2004). The relationships among management accounting information, organizational learning and production performance, The Journal of Strategic Information Systems, 13(1),6185.

Chong, V. \& Chong, K. (1997). Strategic choices, environmental uncertainty and SBU performance: A note on the intervening role of management accounting systems, Accounting and Business Research, V27(4), 268-76.

Daft, R. L., Sormunen, J., \& Parks, D. (1988). Chief executive scanning, environmental characteristics, and company performance. Strategic Management Journal, 9, 123-139.

Daft, R.L. \& Weick, K.E. (1984). Toward a model of organizations as interpretation systems, Academy of Management Review, 9(2), 284-295. 
Davis, S. \& Albright, T. (2004). An investigation of the effect of Balanced Scorecard implementation on financial performance. Management Accounting Research. 15. 135-153.

Ferris, K. \& Haskins, M. (1988). Perspectives on accounting systems and human behaviour, Accounting, Auditing \& Accountability Journal, 1(2), 3-18.

Finkelstein, S. \& Hambrick, D.C. (1996). Strategic Leadership: Top Executives and Their Effects on Organizations. West Publishing Company.

Fisher, J.G. (1995). Contingency-based research on management control systems: categorization by level of complexity, Journal of Accounting Literature, 14, 24-53.

Floren, H. \& Tell, J. (2012). Managerial behaviour in small firms: Does it matter what managers do? In Tengblad, S. (ed.), The Work of Managers: Towards a Practice Theory of Management, Oxford University Press. UK.

Fornell, C. \& Larcker, D.F. (1981). Evaluating structural equation models with unobservable variables and measurement error, Journal of Marketing Research, 18(1), 39-50.

Fox, P. (1992). Exploring managers' jobs, Management Decision, 30(6), 52-63.

Gordon, L. \& Narayanan, V.K. (1984). Management accounting systems, perceived environmental uncertainty and organization structure: An empirical investigation. Accounting, Organizations and Society, 9(1), pages 33-47.

Gottschalk, P. (2002). The Chief Information Officer: a study of managerial roles in Norway, Proceedings of the 35th Hawaii International Conference on System Sciences. Hawaii.

Gul, F. \& Chia, Y. M. (1994). The Effects of Management Accounting Systems, Perceived Environmental Uncertainty and Decentralization on Managerial Performance: A Test of Threeway Interaction. Accounting, Organizations and Society, 19: 413-426.

Hall, M. (2010). Accounting information and managerial work, Accounting, Organizations and Society, 35(3), 301-315.

Hambrick, D. \& Mason, P. (1984). Upper echelons: the organization as a reflection of its top managers, Academy of Management Review, 9(2), 193-206.

Harrison, A.M. (1978). The operational definition of managerial roles (Unpublished Doctoral dissertation), University of Cape Town.

Hart, S.L. \& Quinn, R.E. (1993). Roles executives play: CEOs, behavioral complexity and firm performance. Human Relations, 46 (5): 543-574.

Henseler, J., Ringle, C.M. \& Sinkovics, R.R. (2009). The use of partial least squares path modeling in international marketing, Advances in International Marketing, 20, 277-319.

Hernez-Broome, G. \& Hughes, R.L. (2004). Leadership Development: Past, Present, and Future. Human Resource Planning, 27(1), 24-32.

Hopwood, A. (2007). Whither accounting research, The Accounting Review, 82(5), 1365-1374.

Hoque, Z. (2001). Strategic Management Accounting: Concepts, processes and issues. Chandos Publishing. UK.

Hoque, Z. \& James, W. (2000). Linking balanced scorecard measures to size and market factors: Impact on organizational performance, Journal of Management Accounting Research, 12(1), 1-17.

Idris, F. \& Ali, K.A.M. (2008). The impacts of leadership style and best practices on company performances: Empirical evidence from business firms in Malaysia, Total Quality Management \& Business Excellence, 19(1-2), 165-173. 
Ittner, C.D. \& Larcker, D.F. (1998). Innovations in performance measurement: trends \& research implications, Journal of Management Accounting Research, 10, 205-238.

Ittner, C. D., D. F. Larcker \& M. W. Meyer (2003). Subjectivity and the Weighting of Performance Measures: Evidence from a Balanced Scorecard, The Accounting Review, 78(2), 725-758.

Johnson, H.T \& Kaplan, R. (1987). Relevance Lost: The Rise and Fall of Management Accounting, Harvard Business School Press, Boston.

Jönsson, S. (1998). Relate management accounting research to managerial work! Accounting, Organizations and Society, 23(4), 411-34.

Kaiser, H. F. (1960). The application of electronic computers to factor analysis. Educational and Psychological Measurement, 20, 141-151.

Kaplan, R.S. \& Norton, D.P. (1992).The balanced scorecard - measures that drive performance, Harvard Business Review, 70(1/2), 71-79.

Kaplan, R.S. \& Norton, D.P. (1996).The balanced scorecard - translating strategy into action, Harvard Business School Press, Boston, Massachusetts.

Kaplan, R.S. \& Norton, D.P. (1996b). Using the Balanced Scorecard as a Strategic Management System, Harvard Business Review, January-February, 75-85.

Khandwalla, P. (1972). The effects of different types of competition on the use of management controls, Journal of Accounting Research, 10(3), 275-295.

Kotter, J.P. (1982). The General Managers, New York: The Free Press.

Kurke, L.B. \& Aldrich, H.E. (1983). Note - Mintzberg was Right! A Replication and Extension of The Nature of Managerial Work, Management Science, 29(8), 975-984.

Laitinen, E.K. (2014). The association between CEO work, management accounting information, and financial performance: evidence from Finnish top managers, Journal of Management Control, 25(3): 221-257.

Lawrence, P. R. \& Lorsch, J.W. (1987). Organization and Environment: Managing Differentiation and Integration, Harvard Business School Classics ed., Harvard Business School Press, Boston.

Ling, Y., Simsek, Z., Lubatkin, M.H. \& Veiga, J.F. (2008). The impact of transformational CEOs on the performance of small- to medium- sized firms: Does organizational context matter. Journal of Applied Psychology, 93 (4): 923-934.

Lubatkin, M.H., Ndiaye, M. \& Vengroff, R. (1977). The nature of managerial work in developing countries: a limited test of the universalist hypothesis, Journal of International Business Studies, 28(4), 711-734.

Luft, J. \& Shields, M.D. (2003). Mapping management accounting: Graphics and guidelines for theory-consistent empirical research. Accounting, Organizations and Society, 28(2-3), 169-249.

Luthans, F., Rosenkrantz, S.A. \& Hennessey, H.W. (1985). What Do Successful Managers Really Do? An Observation Study of Managerial Activities, Journal of Applied Behavioral Science, 21(3), 255-270.

Malmendier, U. \& Tate, G. (2005). CEO overconfidence and corporate investment, The journal of Finance, 60(6), 2661-2700.

Masi, R. \& Cooke, R. 2000. Effects of transformational leadership on subordinate motivation, empowering norms, and organizational productivity. International Journal of Organizational Analysis, 8, 16-47. 
McKinnon, S.M. \& Bruns, W.J., Jr. (1992). The Information Mosaic. Harvard: Harvard Business School Press.

Mia, L. (1989). The impact of participation in budgeting and job difficulty on managerial performance and work motivation: A research note, Accounting, Organizations and Society, 14(4), 347-57.

Mia, L. (1993). The role of MAS information in organization: An empirical study, British Accounting Review, 25, 269-85.

Mia, L. \& Chenhall, R. (1994). The usefulness of management accounting systems, functional differentiation and managerial effectiveness, Accounting, Organizations and Society, 19(1),1-13. Mia, L. \& Clarke, B. (1999). Market competition, management accounting systems \& business unit performance, Management Accounting Research, 10(2), 137-158.

Mintzberg, H. (1971). Managerial work: analysis from observation, Management Science, 18(2), 97-110.

Mintzberg, H. (1973). The Nature of Managerial Work. New York: Harper \& Row.

Mintzberg, H. (1976). The manager's job: folklore and fact, Harvard Business Review, 53(4), 4961.

Mintzberg, H. (1979). The structuring of organizations. Englewood Cliffs, N.J., Prentice-Hall.

Mintzberg, H. (1994). Rounding out the manager's job, Sloan Management Review, 35(2), 11-26. Neely, A. (2008). Does the balanced scorecard work: An empirical investigation. Cranfield University. School of Management. Research paper no. 1/08. Cranfield.

Nicolini, D. (2012). Practice Theory, Work and Organization. An Introduction, Oxford University Press.

Noordegraaf, M. \& Stewart, R. (2000). Managerial behaviour research in private and public sectors: distinctiveness, disputes and directions, Journal of Management Studies, 37(3), 427443.

Norreklit, H. (2000). The balance on the balanced scorecard - a critical analysis of some of its assumptions, Management Accounting Research, 11(1), 65-88.

Pavett, C. M. \& Lau, A.W. (1982). Management roles, skills, and effective performance. Academy of Management Proceedings, 95-99.

Perera, S., Harrison, G. \& Poole, M. (1997). Customer-focused manufacturing strategy and the use of operations-based non-financial performance measures: A research note, Accounting, Organizations and Society, 22(6), 557-72.

Sah, R.K. \& Stiglitz, J.E. (1991). The quality of managers in centralized versus decentralized organizations. Quarterly Journal of Economics, 106, 289-295.

Sharma, R., Jones, S. \& Ratnatunga, J. (2006). The relationships among broad scope MAS, managerial control, performance, and job relevant information: a concomitant analysis, Review of Accounting \& Finance, 5(3), 228-250.

Simons, R. (1991). Strategic orientation and top management attention to control systems, Strategic Management Journal, 12(1), 49-62.

Smith, D. \& Langfield-Smith, K. (2004). Structural equation modeling in management accounting research: critical analysis and opportunities, Journal of Accounting Literature, 23, 49-86.

Stage, F.K., Carter, H. \& Nora, A. (2004). Path Analysis: an introduction and analysis of a decade of research, Journal of Educational Research, 98(1), 5-12. 
Stewart, R. (1982). A model for understanding managerial jobs and behavior, The Academy of Management Review, 7(1): 7-13.

Stewart, R. (1988). Managers and their Jobs. London: MacMillan Press.

Stewart, R. \& Fondas, N. (1992). How managers can think strategically about their jobs, The Journal of Management Development, 11(2),10-17.

Temme, D., Kreis, H. \& Hildebrandt, L. (2006). PLS Path Modeling - A Software Review. SFB 649 Discussion Papers SFB649DP2006-084, Sonderforschungsbereich 649, Humboldt University, Berlin, Germany.

Tengblad, S. (2002). Time and space in managerial work, Scandinavian Journal of Management, 18(4), 543-565.

Tengblad, S. (2006). Is there a 'New Managerial Work'? A Comparison with Henry Mintzberg's Classic Study 30 Years Later. Journal of Management Studies, 43(7), 1437-1461.

Tengblad, S. (ed.) (2012). The Work of Managers: Towards a Practice Theory of Management,

Oxford University Press. UK.

Tillema, S. (2005). Towards an integrated contingency framework for MAS sophistication: case studies on the scope of accounting instruments in Dutch power and gas companies, Management Accounting Research, 16(1), 101-129.

Tosi, H.L., Misangyi, V.F., Fanelli, A., Waldman, D.A. \& Yammarino, F.J. (2004). CEO charisma, compensation, and firm performance, The Leadership Quarterly, 15, 405-420.

Tripsas, M. and Gavetti, G. (2000). Capabilities, Cognition, and Inertia: Evidence from Digital Imaging, Strategic Management Journal, 21(11), 1147-1161.

Waldman, A., Javidan, M. \& Varella, P. (2004). Charismatic leadership at the strategic level: A new application of upper echelons theory, Leadership Quarterly, 15 (3): 355-380.

Waldman, D.A., Ramirez, G.G., House, R.J. \& Puranam, P. (2001). Does leadership matter? CEO leadership attributes and profitability under conditions of perceived environmental uncertainty. Academy of Management Journal, 44 (1): 134-143.

Yukl, G. (2012). Effective Leadership Behavior: What We Know and What Questions Need More Attention. Academy of Management Perspectives, November, 66-85.

Zhao, X., Lynch, J. G. Jr. \& Chen, Q. (2010). Reconsidering Baron and Kenny: Myths and truths about mediation analysis. Journal of Consumer Research, 37, 197-206. 


\section{APPENDICES}

\section{Appendix 1. The questionnaire}

\section{Managerial work role}

How important do you consider the following twenty tasks in your managerial work? (Use the following scale to assess importance: 1 = no importance at all, 2 = very little importance, $3=$ moderately little importance, $4=$ average importance, $5=$ moderately much importance, $6=$ very much importance, $7=$ extremely much importance)

(For the managerial tasks, see Table 1)

\section{The importance of the broad scope of information}

How important do you consider the following types of information in your managerial work? (Use the following scale to assess importance: 1 = no importance at all, $2=$ very little importance, $3=$ moderately little importance, $4=$ average importance, 5 = moderately much importance, $6=$ very much importance, $7=$ extremely much importance)

a. Information on events with in the firm (for example, firm growth, profitability, efficiency, productivity, employee motivation, process performance)

b. Information on events outside the firm (for example, markets, customer, competitor, subcontractor characteristics)

c. Information expressed in financial terms (for example, financial statements, cost, financial budgets, prices)

d. Information expressed in non-financial terms (for example, employee motivation, customer satisfaction, throughput times, elasticity, product quality)

e. Information related to past events (for example, last financial statements, realized budgets, last period throughput times, previous period product quality)

f. Information related to future events mechanically based on past events (for example, trends based on past figures, time-series forecasted change in motivation, and in prices)

g. Information related to future events based on new action plans (for example, operative action plans, strategic investment plans, and their influence on future employee motivation, efficiency, and labor satisfaction)

\section{Perceived environmental uncertainty (PEU)}

What is the level of inaccuracy you can predict changes in the business environment of your firm for a 2-4 years horizon? (Pick one: 1 = extremely low, 2 = very low, $3=$ moderately low, $4=$ average, $5=$ moderately high, $6=$ very high, 7 = extremely high) 
Appendix 2. Cross Loadings of the latent variables.

\begin{tabular}{|l|r|r|}
\hline & Profitability & \multicolumn{1}{l|}{ Scope } \\
\hline Return on investment ratio 2010 & 0,7543 & 0,1295 \\
\hline Return on investment ratio 2011 & 0,8167 & 0,1225 \\
\hline Return on assets ratio 2010 & 0,7837 & 0,0903 \\
\hline Return on assets ratio 2011 & 0,8177 & 0,0688 \\
\hline EBIT to sales ratio 2010 & 0,6592 & 0,0216 \\
\hline EBIT to sales ratio 2011 & 0,7355 & 0,1435 \\
\hline Information on events within the firm & 0,0947 & 0,6719 \\
\hline Information on events outside the firm & 0,1583 & 0,6228 \\
\hline Information expressed in financial terms & $-0,0056$ & 0,7604 \\
\hline $\begin{array}{l}\text { Information expressed in non-financial } \\
\text { terms }\end{array}$ & 0,1212 & 0,6061 \\
\hline \begin{tabular}{l} 
Information related to past events \\
\hline $\begin{array}{l}\text { Information related to future events } \\
\text { mechanically based on past events }\end{array}$
\end{tabular} & 0,0370 & 0,7937 \\
\hline $\begin{array}{l}\text { Information related to future events based } \\
\text { on new action plans }\end{array}$ & 0,1046 & 0,7903 \\
\hline
\end{tabular}




\section{TABLES}

Table 1. Mintzberg (1973) ten work roles by the three categories with exemplary tasks.

\begin{tabular}{|c|}
\hline A. INTERPERSONAL CATEGORY OF ROLES \\
\hline 1. FIGUREHEAD \\
\hline Task 1: Present employees with prizes or certificates at ceremonies. \\
\hline Task 2: Represent the organization on outside bodies or at public functions. \\
\hline 2. LEADER \\
\hline Task 3: Conduct employment, disciplinary or appraisal interviews. \\
\hline Task 4: Hold regular meetings with subordinates. \\
\hline 3. LIAISON \\
\hline Task 5: Regularly hold discussions with colleagues in other organizations. \\
\hline Task 6: Acknowledge mail from other organizations. \\
\hline B. INFORMATIONAL CATEGORY OF ROLES \\
\hline 4. MONITOR \\
\hline Task 7: Regularly make tours of inspection around workplace. \\
\hline Task 8: Meet fellow managers to discuss mutual problems. \\
\hline 5. DISSEMINATOR \\
\hline Task 9: Transmit information to subordinates or other appropriate persons in organization. \\
\hline Task 10: Hold review sessions regarding information with subordinates or other appropriate persons. \\
\hline 6. SPOKESMAN \\
\hline Task 11: Regularly hold discussions with own supervisor or Board. \\
\hline Task 12: Act as expert or spokesman for section or organization. \\
\hline C. DECISIONAL CATEGORY OF ROLES \\
\hline 7. ENTREPRENEUR \\
\hline Task 13: Supervise design and implementation of organizational projects. \\
\hline Task 14: Seek opportunities in environment to initiate improvements in organization. \\
\hline 8. DISTURBANCE HANDLER \\
\hline Task 15: Adjudicate sudden conflicts (over many issues) amongst subordinates. \\
\hline Task 16: Hold strategy sessions when problems arise that threaten section or organization. \\
\hline 9. RESOURCE ALLOCATOR \\
\hline Task 17: Set programme and/or budget for section or organization and review regularly. \\
\hline Task 18: Schedule work programme and review and change as needed. \\
\hline 10. NEGOTIATOR \\
\hline Task 19: Represent section or organization at negotiations with outside groups such as union or suppliers. \\
\hline
\end{tabular}


Table 2. Four-factor solution for importance of managerial task variables.

Panel 1. Eigenvalues and variance explained by the factors.

\begin{tabular}{|c|c|c|c|c|c|c|}
\hline \multicolumn{4}{|c|}{ Initial Eigenvalues } & \multicolumn{3}{|c|}{$\begin{array}{l}\text { Rotation Sums of Squared } \\
\text { Loadings }\end{array}$} \\
\hline Factor & Total & $\begin{array}{l}\% \text { of } \\
\text { Variance }\end{array}$ & $\begin{array}{l}\text { Cumulative } \\
\%\end{array}$ & Total & $\begin{array}{l}\% \text { of } \\
\text { Variance }\end{array}$ & $\begin{array}{l}\text { Cumulative } \\
\%\end{array}$ \\
\hline 1 & 6,977 & 34,884 & 34,884 & 3,395 & 16,976 & 16,976 \\
\hline 2 & 1,788 & 8,938 & 43,823 & 2,895 & 14,475 & 31,452 \\
\hline 3 & 1,363 & 6,817 & 50,640 & 1,881 & 9,407 & 40,859 \\
\hline 4 & 1,095 & 5,474 & 56,114 & 1,230 & 6,152 & 47,011 \\
\hline 5 & 0,998 & 4,988 & 61,102 & & & \\
\hline 6 & 0,851 & 4,255 & 65,357 & & & \\
\hline 7 & 0,829 & 4,147 & 69,504 & & & \\
\hline 8 & 0,713 & 3,565 & 73,069 & & & \\
\hline 9 & 0,625 & 3,126 & 76,195 & & & \\
\hline 10 & 0,616 & 3,082 & 79,277 & & & \\
\hline
\end{tabular}


Panel 2. Varimax-rotated factor loadings on the 20 tasks.

Factor

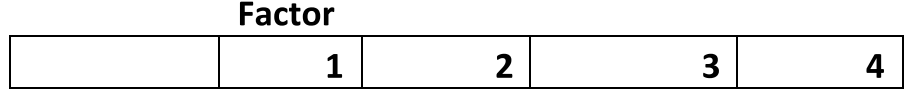

A. INTERPERSONAL CATEGORY OF ROLES

1. FIGUREHEAD

\begin{tabular}{|l|r|r|r|r|}
\hline Task 1 & 0,505 & 0,163 & 0,068 & 0,324 \\
\hline Task 2 & 0,195 & 0,251 & 0,204 & $\mathbf{0 , 9 2 5}$ \\
\hline
\end{tabular}

\section{LEADER}

\begin{tabular}{|l|r|r|r|r|}
\hline Task 3 & 0,463 & 0,094 & 0,261 & 0,252 \\
\hline Task 4 & 0,511 & 0,303 & 0,092 & 0,177 \\
\hline
\end{tabular}

3. LIAISON

\begin{tabular}{|l|r|r|r|r|}
\hline Task 5 & 0,300 & 0,280 & 0,157 & 0,004 \\
\hline Task 6 & 0,368 & 0,050 & 0,359 & 0,121 \\
\hline
\end{tabular}

\section{B. INFORMATIONAL CATEGORY OF ROLES}

4. MONITOR

\begin{tabular}{|l|r|r|r|r|}
\hline Task 7 & $\mathbf{0 , 5 7 4}$ & 0,056 & 0,102 & $-0,056$ \\
\hline Task 8 & 0,399 & 0,360 & 0,169 & 0,113 \\
\hline
\end{tabular}

5. DISSEMINATOR

\begin{tabular}{|l|r|r|r|r|}
\hline Task 9 & $\mathbf{0 , 6 8 4}$ & 0,105 & 0,102 & 0,097 \\
\hline Task 10 & $\mathbf{0 , 6 0 2}$ & 0,252 & 0,165 & 0,117 \\
\hline
\end{tabular}

6. SPOKESMAN

\begin{tabular}{|l|l|l|l|l|}
\hline Task 11 & 0,267 & 0,529 & 0,009 & 0,159 \\
\hline Task 12 & 0,113 & 0,551 & 0,307 & 0,148 \\
\hline
\end{tabular}

\section{DECISIONAL CATEGORY OF ROLES}

7. ENTREPRENEUR

\begin{tabular}{|l|r|r|r|r|}
\hline Task 13 & 0,129 & $\mathbf{0 , 7 5 7}$ & 0,184 & $-0,030$ \\
\hline Task 14 & 0,067 & $\mathbf{0 , 7 8 9}$ & 0,107 & 0,155 \\
\hline
\end{tabular}

8. DISTURBANCE HANDLER

\begin{tabular}{|l|r|r|r|r|}
\hline Task 15 & 0,486 & 0,234 & 0,344 & 0,046 \\
\hline Task 16 & 0,486 & 0,490 & 0,308 & 0,074 \\
\hline
\end{tabular}

9. RESOURCE ALLOCATOR

\begin{tabular}{|l|r|r|r|r|}
\hline Task 17 & 0,529 & 0,458 & 0,167 & 0,120 \\
\hline Task 18 & 0,405 & 0,023 & 0,419 & $-0,010$ \\
\hline
\end{tabular}

10. NEGOTIATOR

\begin{tabular}{|l|l|l|l|l|}
\hline Task 19 & 0,230 & 0,252 & $\mathbf{0 , 6 8 3}$ & 0,085 \\
\hline Task 20 & 0,077 & 0,260 & $\mathbf{0 , 7 1 2}$ & 0,139 \\
\hline
\end{tabular}

Note: For task descriptions, see Table 1 
Table 3. Descriptive statistics of the model variables.

Panel 1. Mintzberg managerial task variables.

A. INTERPERSONAL CATEGORY OF ROLES

\begin{tabular}{|c|c|c|c|c|c|c|}
\hline 1. FIGUREHEAD & Mean & $\begin{array}{l}\text { Standard } \\
\text { Deviation }\end{array}$ & Skewness & Kurtosis & $\begin{array}{l}\text { Factor } \\
\text { number }\end{array}$ & $\begin{array}{l}\text { Factor } \\
\text { loading }\end{array}$ \\
\hline Task 1 & 3,360 & 1,376 & $-0,020$ & $-0,845$ & 1 & 0,505 \\
\hline Task 2 & 4,090 & 1,276 & $-0,269$ & $-0,474$ & 4 & 0,925 \\
\hline \multicolumn{7}{|l|}{ 2. LEADER } \\
\hline Task 3 & 3,690 & 1,215 & 0,017 & $-0,466$ & 1 & 0,463 \\
\hline Task 4 & 4,490 & 1,112 & $-0,653$ & 1,043 & 1 & 0,511 \\
\hline \multicolumn{7}{|l|}{ 3. LIAISON } \\
\hline Task 5 & 4,110 & 1,163 & $-0,043$ & $-0,198$ & 1 & 0,300 \\
\hline Task 6 & 3,200 & 1,006 & 0,080 & $-0,683$ & 1 & 0,368 \\
\hline
\end{tabular}

\section{B. INFORMATIONAL CATEGORY OF ROLES}

\begin{tabular}{|l|r|r|r|r|r|r|}
\hline 4. MONITOR & & & & & & \\
\hline Task 7 & 3,210 & 1,430 & 0,074 & $-0,912$ & 1 & 0,574 \\
\hline Task 8 & 4,070 & 1,476 & $-0,462$ & $-0,318$ & 1 & 0,399 \\
\hline 5. DISSERMINATOR & & & & & & \\
\hline Task 9 & 3,900 & 1,271 & $-0,240$ & $-0,475$ & 1 & 0,684 \\
\hline Task 10 & 3,960 & 1,136 & $-0,280$ & 0,105 & 1 & 0,602 \\
\hline 6. SPOKESMAN & & & & & & \\
\hline Task 11 & 3,810 & 1,596 & $-0,436$ & $-0,644$ & 2 & 0,529 \\
\hline task 12 & 4,180 & 1,394 & $-0,484$ & 0,067 & 2 & 0,551 \\
\hline
\end{tabular}

C. DECISIONAL CATEGORY OF ROLES

C. DECISIONAL CATEGORY OF ROLES
\begin{tabular}{|l|r|r|r|r|r|r|}
\hline 7. ENTREPRENEUR & & & & & & \\
\hline Task 13 & 4,600 & 1,247 & $-0,737$ & 0,992 & 2 & 0,757 \\
\hline Task 14 & 4,850 & 1,167 & $-0,755$ & 0,981 & 2 & 0,789 \\
\hline 8. DISTURBANCE HANDLER & & & & & & \\
\hline Task 15 & 3,920 & 1,377 & $-0,087$ & $-0,653$ & 1 & 0,486 \\
\hline Task 16 & 4,200 & 1,373 & $-0,230$ & $-0,274$ & 2 & 0,490 \\
\hline 9. RESOURCE ALLOCATOR & & & & & & \\
\hline Task 17 & 4,220 & 1,359 & $-0,452$ & $-0,198$ & & 1 \\
\hline task 18 & 4,120 & 1,278 & $-0,028$ & $-0,236$ & 3 & 0,529 \\
\hline 10. NEGOTIATOR & & & & & & 0,419 \\
\hline Task 19 & 3,860 & 1,471 & $-0,121$ & $-0,640$ & 3 & 0,683 \\
\hline task 20 & 4,340 & 1,325 & $-0,409$ & $-0,343$ & 3 & 0,712 \\
\hline
\end{tabular}

Notes: 
For description of the tasks, see Table 1

Scale from 1 = not important at all to 7 = extremely important in managerial work

Factor $=$ Number of the factor with highest loading for the task

Panel 2. The items of the importance of information scope (SCOPE) construct.

\begin{tabular}{|l|l|l|l|l|l|l|}
\hline Item of information scope & Mean & $\begin{array}{l}\text { Standard } \\
\text { Deviation }\end{array}$ & Skewness & Kurtosis & Loading & $p$-value \\
\hline
\end{tabular}

A. Focus dimension
\begin{tabular}{|l|r|r|r|r|r|r|}
\hline Information on events within the firm & 5,770 & 1,001 & $-0,880$ & 0,781 & 0,672 & 0,000 \\
\hline Information on events outside the firm & 5,680 & 1,030 & $-1,315$ & 2,845 & 0,623 & 0,000 \\
\hline
\end{tabular}

\section{B. Quantification dimension}

B. Quantification dimension
\begin{tabular}{|l|r|r|r|r|r|r|}
\hline $\begin{array}{l}\text { Information expressed in financial } \\
\text { terms }\end{array}$ & 5,240 & 1,076 & $-0,471$ & $-0,609$ & 0,760 & 0,000 \\
\hline $\begin{array}{l}\text { Information expressed in non-financial } \\
\text { terms }\end{array}$ & 5,440 & 0,857 & $-0,495$ & 0,186 & 0,606 & 0,000 \\
\hline
\end{tabular}

\section{Time horizon dimension}

\begin{tabular}{|l|r|r|r|r|r|r|}
\hline Information related to past events & 4,470 & 1,155 & $-0,022$ & $-0,296$ & 0,794 & 0,000 \\
\hline $\begin{array}{l}\text { Information related to future events } \\
\text { mechanically based on past events }\end{array}$ & 4,290 & 1,266 & $-0,157$ & $-0,342$ & 0,790 & 0,000 \\
\hline $\begin{array}{l}\text { Information related to future events } \\
\text { based on new action plans }\end{array}$ & 4,730 & 1,222 & $-0,524$ & 0,449 & 0,738 & 0,000 \\
\hline
\end{tabular}

\section{Notes:}

Scale from $1=$ not significant at all to $7=$ extremely significant

Loading = outer loading in the PLS analysis

$p$-value $=$ probability level for the loading

Panel 3. The items of the profitability (PROFITABILITY) construct.

\begin{tabular}{|l|r|r|r|r|r|r|}
\hline & Mean & $\begin{array}{l}\text { Standard } \\
\text { Deviation }\end{array}$ & Skewness & Kurtosis & \multicolumn{1}{c|}{ Loading } & $\boldsymbol{p}$-value \\
\hline Item of information perspective & 14,546 & 33,435 & 0,048 & 2,508 & 0,754 & 0,000 \\
\hline Return on investment ratio 2010 & 12,420 & 25,893 & 0,243 & 3,209 & 0,817 & 0,000 \\
\hline Return on investment ratio 2011 & 11,751 & 23,215 & 1,150 & 3,773 & 0,784 & 0,000 \\
\hline Return on assets ratio 2010 & 8,468 & 17,039 & 1,056 & 6,048 & 0,818 & 0,000 \\
\hline Return on assets ratio 2011 & 6,011 & 14,027 & 1,629 & 13,517 & 0,659 & 0,000 \\
\hline EBIT to sales ratio 2010 & 3,909 & 12,725 & $-3,029$ & 26,034 & 0,735 & 0,000 \\
\hline EBIT to sales ratio 2011 & & & & & & \\
\hline
\end{tabular}

Panel 4. Perceived environmental uncertainty (PEU). 


\begin{tabular}{|l|c|r|r|r|}
\hline Moderator variable & Mean & $\begin{array}{r}\text { Standard } \\
\text { Deviation }\end{array}$ & Skewness & Kurtosis \\
\hline Perceived environmental uncertainty & 3,964 & 0,885 & 0,698 & 0,859 \\
\hline
\end{tabular}

Notes:

Scale from 1 = extremely low to 7 = extremely high (see Appendix 1 for the construct) 
Table 4. Statistical summary characteristics of the PLS model.

\begin{tabular}{|l|c|r|r|r|r|r|}
\hline & AVE & $\begin{array}{l}\text { Composite } \\
\text { reliability }\end{array}$ & $\begin{array}{l}\text { R } \\
\text { Square }\end{array}$ & $\begin{array}{l}\text { Cronbach } \\
\text { Alpha }\end{array}$ & Communality & Redundancy \\
\hline Information scope (SCOPE) & 0,5121 & 0,8791 & 0,3039 & 0,8393 & 0,5121 & 0,1065 \\
\hline Profitability (PROFIT) & 0,5824 & 0,8927 & 0,1413 & 0,8562 & 0,5824 & $-0,0013$ \\
\hline
\end{tabular}

Table 5. Path coefficients of the PLS model.

\begin{tabular}{|l|r|r|r|l|}
\hline Path & Coefficient & \multicolumn{1}{l|}{ t statistic } & \multicolumn{1}{l|}{$\boldsymbol{p}$-value } & Hypothesis \\
\hline MWORK1 $\rightarrow$ PROFITABILITY & $-0,1517$ & 1,7347 & 0,0842 & H1: yes \\
\hline MWORK2 $\rightarrow$ PROFITABILITY & 0,0870 & 1,1911 & 0,2349 & H1: no \\
\hline MWORK3 $\rightarrow$ PROFITABILITY & $-0,1571$ & 1,9876 & 0,0481 & H1: yes \\
\hline MWORK4 $\rightarrow$ PROFITABILITY & $-0,0260$ & 0,4169 & 0,6772 & H1: no \\
\hline MWORK1 $\rightarrow$ SCOPE & 0,4155 & 6,9564 & 0,0000 & H2: yes \\
\hline MWORK2 $\rightarrow$ SCOPE & 0,1685 & 2,2785 & 0,0237 & H2: yes \\
\hline MWORK3 $\rightarrow$ SCOPE & 0,1885 & 2,8608 & 0,0046 & H2: yes \\
\hline MWORK4 $\rightarrow$ SCOPE & 0,1775 & 2,6156 & 0,0095 & H2: yes \\
\hline SCOPE $\rightarrow$ PROFITABILITY & 0,1834 & 2,3677 & 0,0188 & H3: yes \\
\hline SCOPE * PEU $\rightarrow$ PROFITABILITY & 0,1722 & 1,3693 & 0,1723 & H4: no \\
\hline MWORK1 * PEU $\rightarrow$ PROFITABILITY & $-0,0647$ & 0,7733 & 0,4402 & H5: no \\
\hline MWORK2 * PEU $\rightarrow$ PROFITABILITY & 0,0127 & 0,1970 & 0,8440 & H5: no \\
\hline MWORK3 * PEU $\rightarrow$ PROFITABILITY & $-0,1742$ & 2,1716 & 0,0310 & H5: yes \\
\hline MWORK4 * PEU $\rightarrow$ PROFITABILITY & 0,1108 & 1,6246 & 0,1057 & H5: (yes) \\
\hline PEU $\rightarrow$ PROFITABILITY & $-0,0009$ & 0,0113 & 0,9910 & \\
\hline NOtS: & & & & \\
\hline
\end{tabular}

\section{Notes:}

$\S=2$-tailed significance

MWORK1 $=$ Emphasis on informational work roles (Factor score 1)

MWORK2 = Emphasis on decisional-informational work roles (Factor score 2)

MWORK3 $=$ Emphasis on decisional work roles (Factor score 3)

MWORK4 = Emphasis on interpersonal work roles (Factor score 4)

SCOPE = Construct of importance of broad information scope

PROFITABILITY = Construct of profitability

$\mathrm{PEU}=$ Construct of perceived environmental uncertainty 
Table 6. Total effects of the PLS model on profitability.

Panel 1. Total effects with direct effects.

\begin{tabular}{|l|r|r|r|}
\hline Path & Coefficient & \multicolumn{1}{c|}{ t statistic } & \multicolumn{1}{c|}{-value } \\
\hline MWORK1 $\rightarrow$ PROFITABILITY & $-0,0755$ & 0,8270 & 0,4092 \\
\hline MWORK1 $\rightarrow$ SCOPE & 0,4155 & 6,9564 & 0,0000 \\
\hline MWORK1 * PEU $\rightarrow$ PROFITABILITY & $-0,0647$ & 0,7733 & 0,4402 \\
\hline MWORK2 $\rightarrow$ PROFITABILITY & 0,1179 & 1,5717 & 0,1175 \\
\hline MWORK2 $\rightarrow$ SCOPE & 0,1685 & 2,2785 & 0,0237 \\
\hline MWORK2 * PEU $\rightarrow$ PROFITABILITY & 0,0127 & 0,1970 & 0,8440 \\
\hline MWORK3 $\rightarrow$ PROFITABILITY & $-0,1225$ & 1,5238 & 0,1290 \\
\hline MWORK3 $\rightarrow$ SCOPE & 0,1885 & 2,8608 & 0,0046 \\
\hline MWORK3 * PEU $\rightarrow$ PROFITABILITY & $-0,1742$ & 2,1716 & 0,0310 \\
\hline MWORK4 $\rightarrow$ PROFITABILITY & 0,0065 & 0,0980 & 0,9220 \\
\hline MWORK4 $\rightarrow$ SCOPE & 0,1775 & 2,6156 & 0,0095 \\
\hline MWORK4 * PEU $\rightarrow$ PROFITABILITY & 0,1108 & 1,6246 & 0,1057 \\
\hline PEU $\rightarrow$ PROFITABILITY & $-0,0009$ & 0,0113 & 0,9910 \\
\hline SCOPE $\rightarrow$ PROFITABILITY & 0,1834 & 2,3677 & 0,0188 \\
\hline SCOPE * PEU $\rightarrow$ PROFITABILITY & 0,1722 & 1,3647 & 0,1738 \\
\hline
\end{tabular}

Panel 2. Total effects of managerial work on profitability without direct effects.

\begin{tabular}{|l|r|r|r|}
\hline Path & Coefficient & \multicolumn{1}{c|}{ t statistic } & \multicolumn{1}{c|}{$\boldsymbol{p}$-value $\S$} \\
\hline MWORK1 $\rightarrow$ PROFITABILITY & 0,0612 & 0,0732 & 0,1845 \\
\hline MWORK2 $\rightarrow$ PROFITABILITY & 0,0248 & 0,0286 & 0,2463 \\
\hline MWORK3 $\rightarrow$ PROFITABILITY & 0,0277 & 0,0305 & 0,2122 \\
\hline MWORK4 $\rightarrow$ PROFITABILITY & 0,0262 & 0,0325 & 0,2847 \\
\hline
\end{tabular}

\section{Notes:}

$\S=2$-tailed significance

MWORK1 = Emphasis on informational work roles (Factor score 1)

MWORK2 = Emphasis on decisional-informational work roles (Factor score 2)

MWORK3 = Emphasis on decisional work roles (Factor score 3)

MWORK4 = Emphasis on interpersonal work roles (Factor score 4)

SCOPE = Construct of importance of broad information scope

PROFITABILITY = Construct of profitability

$\mathrm{PEU}=$ Construct of perceived environmental uncertainty 


\section{FIGURES}

Figure 1. The research model of the study.

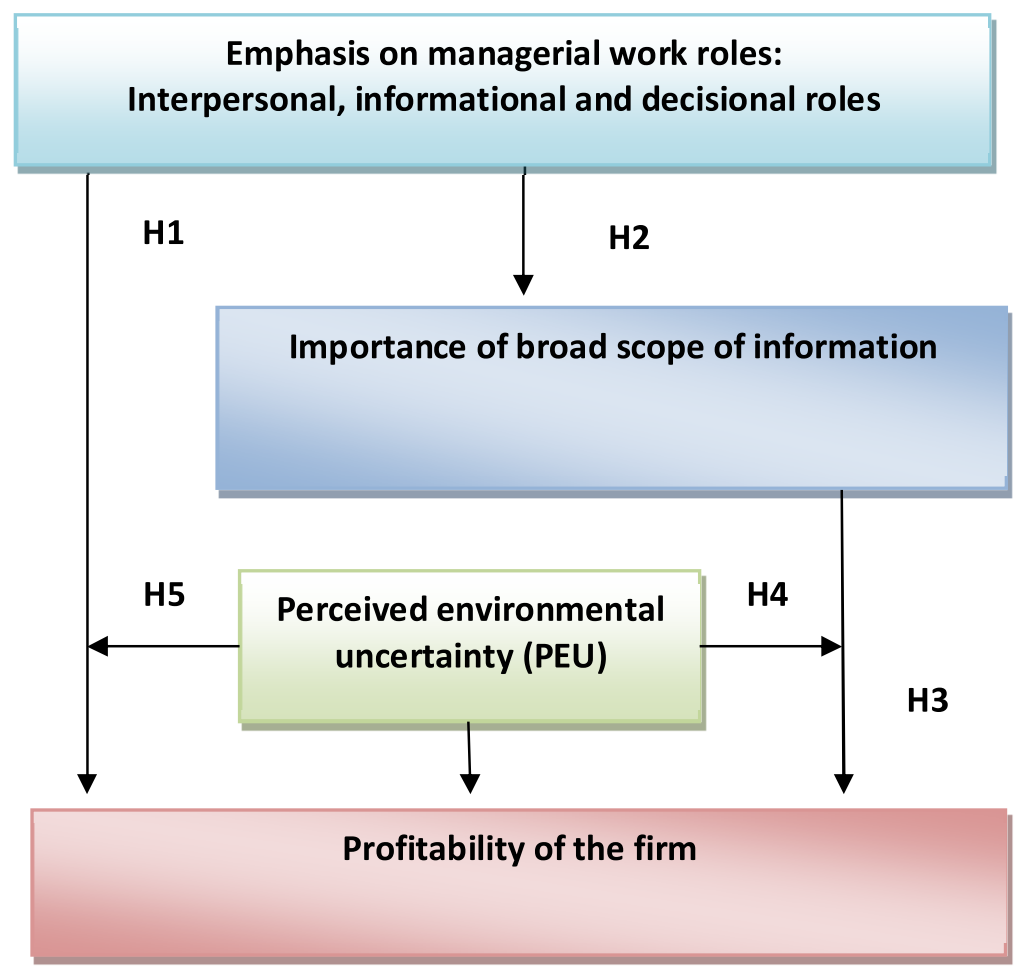


Figure 2. Statistically significant paths in the estimated PLS model.

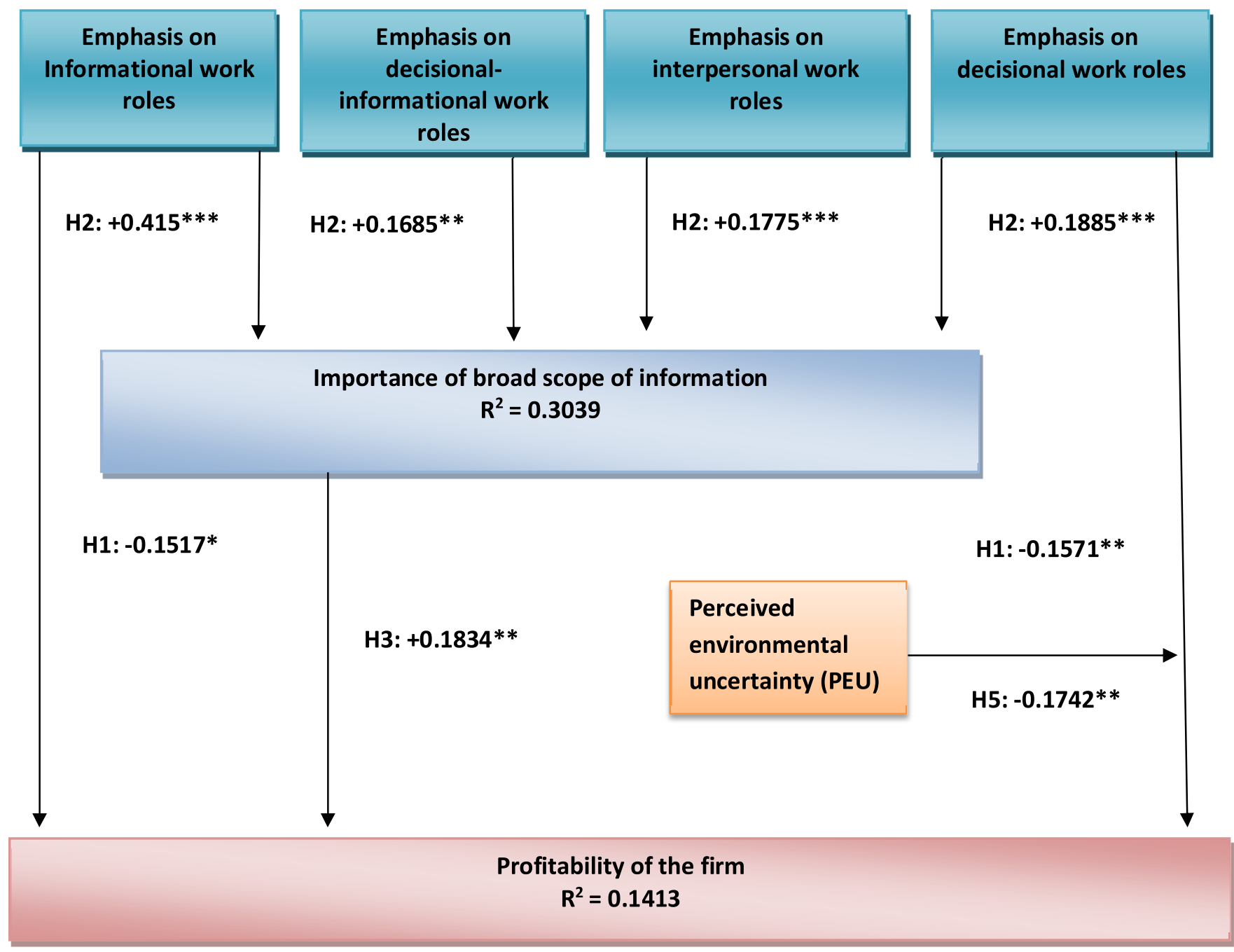

Note: ${ }^{* * *}=p$-value $<0.01,{ }^{* *}=p$-value $<0.05$, and ${ }^{*}=p$-value $<0.1$ (2-tailed) 